\title{
Determinants of the distribution of nitrogen-cycling microbial communities at the landscape scale
}

\author{
D Bru ${ }^{1,2}$, A Ramette ${ }^{3}$, NPA Saby ${ }^{4}$ S Dequiedt ${ }^{1,2,5}$, L Ranjard $^{1,2,5}$, C Jolivet ${ }^{4}$, D Arrouays ${ }^{4}$ \\ and L Philippot ${ }^{1,2}$ \\ ${ }^{1}$ INRA, Department of Soil and Environmental Microbiology, UMR 1229, Dijon, France; ${ }^{2}$ University of \\ Burgundy, Department of Soil and Environmental Microbiology, Dijon, France; ${ }^{3}$ Microbial Habitat Group, \\ Max Planck Institute for Marine Microbiology, Bremen, Germany; ${ }^{4}$ INRA, US 1106 InfoSol, CS 40001, Ardon, \\ Orléans , France and ${ }^{5}$ Platform GenoSol, Dijon, France
}

\begin{abstract}
Little information is available regarding the landscape-scale distribution of microbial communities and its environmental determinants. However, a landscape perspective is needed to understand the relative importance of local and regional factors and land management for the microbial communities and the ecosystem services they provide. In the most comprehensive analysis of spatial patterns of microbial communities to date, we investigated the distribution of functional microbial communities involved in $\mathrm{N}$-cycling and of the total bacterial and crenarchaeal communities over 107 sites in Burgundy, a $31500 \mathrm{~km}^{2}$ region of France, using a $16 \times 16 \mathrm{~km}^{2}$ sampling grid. At each sampling site, the abundance of total bacteria, crenarchaea, nitrate reducers, denitrifiers- and ammonia oxidizers were estimated by quantitative PCR and 42 soil physicochemical properties were measured. The relative contributions of land use, spatial distance, climatic conditions, time, and soil physico-chemical properties to the spatial distribution of the different communities were analyzed by canonical variation partitioning. Our results indicate that $43-85 \%$ of the spatial variation in community abundances could be explained by the measured environmental parameters, with soil chemical properties (mostly $\mathrm{pH}$ ) being the main driver. We found spatial autocorrelation up to $739 \mathrm{~km}$ and used geostatistical modelling to generate predictive maps of the distribution of microbial communities at the landscape scale. The present study highlights the potential of a spatially explicit approach for microbial ecology to identify the overarching factors driving the spatial heterogeneity of microbial communities even at the landscape scale.

The ISME Journal (2011) 5, 532-542; doi:10.1038/ismej.2010.130; published online 12 August 2010

Subject Category: microbial ecology and functional diversity of natural habitats

Keywords: nitrogen cycle; landscape; denitrifiers; ammonia oxidizers; nitrate reducers; biogeography
\end{abstract}

\section{Introduction}

Spatial patterns have long been of concern in ecology and have changed the manner in which studies of plant and animal ecology are designed and analyzed. Characterization of the patterns of species diversity is central for understanding the underlying evolutionary and ecological processes that shape biodiversity across spatial and temporal scales (Levin, 1992). Patterns also have implications for applied ecology, as understanding and predicting spatial patterns are the keys

Correspondence: L Philippot, Department of Soil and Environmental Microbiology, INRA, UMR 1229, 17 rue Sully, Dijon Cedex 21065, France.

E-mail: Laurent.Philippot@dijon.inra.fr

Received 13 April 2010; revised 14 June 2010; accepted 6 July 2010; published online 12 August 2010 for developing ecosystem management strategies (Levin, 1992).

In contrast to plants and animals, studying spatial patterns is recent for microorganisms (Hughes-Martiny et al., 2006; Ramette and Tiedje, 2007a) and an increasing body of literature supports the idea that microbial communities exhibit spatial pattern at different scales. Thus, in terrestrial ecosystems, several studies reported spatial patterns from the centimetre to the meter scale (Nunan et al., 2002; Franklin and Mills, 2003; Ritz et al., 2004; Philippot et al., 2009a). In contrast, only a few studies have investigated spatial patterns of microbial communities over broad spatial scales even though spatial dependence was also observed at the kilometre scale (Cho and Tiedje, 2000; Dequiedt et al., 2009; Yergeau et al., 2009). However, such investigations at broader spatial scales are of importance as it is well known that patterns can change with the scale of description (Hutchinson, 1953). Indeed a landscape perspective is 
needed to understand the impact of human activities, geomorphology or climate on microbial community distribution. Thus, how microorganisms are spatially distributed at the landscape scale and which the factors, among land management, soil physicochemical properties and local climate, governing their distribution are therefore central, yet unanswered, questions despite the fact that microbial communities are essential for biogeochemical cycling and ecosystem functioning.

In this study, we investigated microbial distribution at the landscape scale by focusing on the functional communities involved in nitrogen cycling because traits rather than taxa were suggested to be the fundamental units of biodiversity and biogeography (Weiher and Keddy, 1995). The potential of such a functional trait-based approach to microbial biogeography has recently been further emphasized by Green et al. (2008). Nitrogen-cycling microbial communities such as the ammonia oxidizers, nitrate reducers and denitrifiers have been described as excellent models of functional communities (Kowalchuk and Stephen, 2001; Philippot and Hallin, 2005), of both agronomic and environmental importance. Thus, microbial transformations within the nitrogen cycle affect the bioavailability of nitrogen, which is one of the nutrients that limit plant growth most often limiting for plant growth. Denitrification and ammonia oxidation are also major contributors to the emission of $\mathrm{N}_{2} \mathrm{O}$, a greenhouse gas with $\mathrm{Ca} 300$ times the global warming potential of $\mathrm{CO}_{2}$ (Forster et al., 2007) and the dominant ozone-depleting substance (Ravishankara et al., 2009).

Here, we characterize and explain the spatial variability in the distribution of microbial communities that are involved in nitrogen cycling at the landscape scale. The abundance of the nitratereducing, denitrifying and ammonia-oxidizing communities in soil samples, collected using a grid covering $31500 \mathrm{~km}^{2}$, was quantified by real-time PCR. Canonical variation partitioning was used to examine the relative contributions of land management, spatial distance, climatic conditions, time and more than 40 soil physico-chemical properties to the distribution of each microbial community. We also used geostatistical modelling to investigate the spatial correlations of the microbial communities and produce maps of their distribution at the landscape scale.

\section{Materials and methods}

Experimental site and sampling

Soil sampling was performed using a systematic grid approach. For this purpose, the Burgundy region was divided into 118 cells of about $16 \times 16 \mathrm{~km}^{2}$ and the soil was collected at the center of 107 out of the 118 cells (Supplementary Figure S1). This scale was selected according to the minimum sampling density recommended to monitor soils across Europe (Morvan et al., 2008) and is fully compatible with the unique existing pan-European soil-monitoring network (Lacarce et al., 2009). At each sampling site located in the center of the cell, 25 individual soil cores were collected in the topsoil $(0-30 \mathrm{~cm})$, using an unaligned sampling design within a $20 \times 20 \mathrm{~m}^{2}$ area. The 25 core samples were then composited for each site. Samples of known volume were taken for bulk density determination. Soil samples were air-dried and sieved to $2 \mathrm{~mm}$ before analysis. Soil sampling was achieved thanks to the French Soil Quality Monitoring Network, which collected soil throughout France over a 10-year period using the same $16 \times 16 \mathrm{~km}^{2}$ sampling grid. In Burgundy the 107 soil samples were collected from October 2002 to October 2008 at all seasons (37 in winter, 39 in spring, 13 in summer and 19 in fall).

\section{Soil, climate and land use data}

The following soil characteristics were measured: (i) total organic carbon content and nitrogen measured by dry combustion, (ii) particle-size distribution using five classes (clay $(0-2 \mu \mathrm{m}$ ), fine silt $(2-20 \mu \mathrm{m})$, coarse silt $(20-50 \mu \mathrm{m})$, fine sand $(50-200 \mu \mathrm{m})$ and coarse sand $(200-2000 \mu \mathrm{m})$ using wet sieving and the pipette method (NF X 31-107), (iii) cation exchange capacity and $\mathrm{Ca}, \mathrm{Mg}, \mathrm{K}, \mathrm{Na}, \mathrm{Al}$, Mn exchangeable cations (cobaltihexamin method), (iv) total $\mathrm{K}, \mathrm{Ca}, \mathrm{Mg}, \mathrm{Na}, \mathrm{Fe}, \mathrm{Al}, \mathrm{Cd}, \mathrm{Co}, \mathrm{Cr}, \mathrm{Cu}, \mathrm{Mn}$, $\mathrm{Ni}, \mathrm{Pb}, \mathrm{Tl}, \mathrm{Zn},(\mathrm{v}) \mathrm{pH}$ in water (1:5 soil:water ratio), (vi) extractable boron (boiling water method) and (vii) EDTA-extractable $\mathrm{Cd}, \mathrm{Cr}, \mathrm{Cu}, \mathrm{Ni}, \mathrm{Pb}$ and Zn. Analyses were performed by the Soil Analysis Laboratory of INRA in Arras, France, which is accredited for soil and sludge analysis. Climate data came from the SAFRAN database (Quintana-Segui et al., 2008) and included 1992-2004 averages of monthly and yearly evapotranspiration (ETP), temperature $\left({ }^{\circ} \mathrm{C}\right)$ and rainfall $(\mathrm{mm})$, interpolated on the basis of a $8 \times 8 \mathrm{~km}^{2}$ grid. Land use was classified according to the Corine Land Cover database Classification (Heymann et al., 1994) and grouped in the following broad classes: grasslands, forest, agricultural soil, vineyard and orchards.

\section{DNA extraction}

For each of the 107 samples, DNA was extracted from $250 \mathrm{mg}$ to $1 \mathrm{~g}$ of soil based on the method developed by Martin-Laurent et al. (2001), which is currently under final evaluation by national body members of the ISO before being published as the ISO standard 11063 'Soil quality-Method to directly extract DNA from soil samples'. Even though the comparison for the ISO standardization of DNA extraction from air dried, fresh, and frozen soils from different soils did not show any significant effect on 16S rRNA gene copy number per ng of DNA (unpublished results), we cannot exclude the 
possibility that our results might have been different for some soils with a different procedure. Briefly, samples were homogenized in $1 \mathrm{ml}$ of extraction buffer for $30 \mathrm{~s}$ at 1600 r.p.m. in a minibead beater cell disrupter (Mikro-DismembratorS; B. Braun Biotech International, Melsungen, Germany). Soil and cell debris were eliminated by centrifugation $(14000 \mathrm{~g}$ for $5 \mathrm{~min}$ at $4{ }^{\circ} \mathrm{C}$ ). After precipitation with ice-cold isopropanol, nucleic acids were purified using both polyvinylpyrrolidone and Sepharose 4B spin columns. Quality and size of soil DNA were checked by electrophoresis on 1\% agarose. DNA was quantified using the Quant-iT dsDNA Assay Kit (Invitrogen, Paisley, UK) and a plate reader (Berthold Mithras LB940, Thoiry, France).

\section{Real-time PCR quantification ( $q P C R$ )}

The total bacterial and crenarcheal communities were quantified using 16S rRNA primer-based qPCR assays described previously (Ochsenrelter et al., 2003). Quantification of the bacterial and crenarchaeal ammonia oxidizers was performed according to Leininger et al. (2006) and Tourna et al. (2008) whereas quantification of nitrate reducers and denitrifiers was performed according to Bru et al. (2007) and Henry et al. (2004, 2006), respectively. For this purpose, the genes encoding catalytic enzymes of ammonia oxidation (bacterial and crenarchaeal $a m o A$ ), nitrate reduction (narG and nap $A$ ) and denitrification (nirK, nirS and nosZ) were used as molecular markers. Reactions were carried out in an ABI prism 7900 Sequence Detection System (Applied Biosystems, Carlsbad, CA, USA). Quantification was based on the increasing fluorescence intensity of the SYBR Green dye during amplification. The real-time PCR assay was carried out in a $20 \mu \mathrm{l}$ reaction volume containing the SYBR green PCR Master Mix (Absolute QPCR SYBR Green Rox, ABgene, Courtaboeuf, France), $1 \mu \mathrm{M}$ of each primer, $100 \mathrm{ng}$ of T4 gene 32 (QBiogene, Illkrich, France) and $0.5-2$ ng of DNA. Two independent quantitative PCR assays were performed for each gene. Standard curves were obtained using serial dilutions of linearized plasmids containing the studied genes. PCR efficiency for the different assays ranged between 86 and $99 \%$. Two to three notemplate controls were run for each quantitative PCR assay and no template controls gave null or negligible values. The presence of PCR inhibitors in DNA extracted from soil was estimated by (i) diluting the soil DNA extract and (ii) mixing a known amount of standard DNA with soil DNA extract prior to qPCR. No inhibition was detected in either case.

As the number of $16 \mathrm{~S}$ rRNA operons per cell is variable (Klappenbach et al., 2001) the 16S rRNA gene copy data were not converted into cell numbers and the results were expressed as 16S rRNA gene copy numbers per ng of extracted DNA. Calculation of the gene copy number per ng of DNA rather than per gram of soil minimizes the bias related to possible differences in the DNA extraction yield between samples. To obtain an estimate of the relative abundance of the different functional communities within the total bacterial or crenarchaeal communities in the samples, we calculated ratios between the ammonia-oxidation, nitrate reduction and denitrification gene copy numbers and the total bacterial 16S rRNA gene copy number ratios, and between the crenarchaeal ammonia oxidation gene copy numbers and the crenarchaeal 16S rRNA gene copy number ratio.

\section{Statistical analyses}

All quantitative (response and explanatory) data were transformed using Box-Cox transformation prior to analyses (the corresponding lamba parameters were estimated by maximum likelihood (Cook and Weisberg, 1999)). Qualitative explanatory variables were transformed into dummy variables. Spatial vectors were constructed by using the Principal Coordinate of a Neighbor Matrix (PCNM) approach (Borcard and Legendre, 2002). This spatial decomposition method was applied to the geographic coordinates of the samples (data were spatially detrended if necessary), which yielded 62 spatial variables that represented all spatial scales present in the sampling scheme. The order of the PCNM variables corresponds to a progression from larger to smaller spatial scales (Borcard et al., 2004). For each response data model, the most significant PCNM variables were chosen by permutational forward model selection and by ensuring that the adjusted $R^{2}$ of the reduced models did not exceed the adjusted $R^{2}$ of the global models. Explanatory variables were then selected by multiple regression analysis using stepwise selection and by minimizing the Akaike Information Criterion. Statistical significances were assessed by 1000 permutation of the reduced models. The respective effects of each explanatory variable, or combinations thereof, were determined by canonical variation partitioning (Borcard et al., 1992; Ramette and Tiedje, 2007b). $P$ values were Bonferroni-corrected to maintain the family-wise error level in multiple testing. All statistical calculations were performed with the $\mathrm{R}$ statistical platform using the vegan, PCNM and MASS packages.

\section{Geostatistical interpolation}

Kriging or geostatistical interpolation aims to predict the unknown value of a variable $Z$ at a non-observed location $X_{i}$ using the value $Z_{i}$ at surrounding locations. For this purpose, a stochastic function was used as a model of spatial variation so that the actual but unknown value $z\left(\boldsymbol{x}_{\mathrm{i}}\right)$ and the value at the surrounding location were spatially dependent random variables. A Box-Cox transformation was applied to our data (Box and Cox, 
1964) so that $\mathbf{z}$ was a realization of a Gaussian random function with a covariance matrix $\mathbf{V}$.

$$
Z^{*}=\left\{\begin{array}{cc}
\log (z) & \text { if } t=0 \\
\frac{z^{t}-1}{t} & \text { otherwise }
\end{array}\right.
$$

where $t$ is the parameter of the transformation.

The elements of $\mathbf{V}$ are expressed as a function of the distance separating two observations (h). The elements of $\mathbf{V}$ are obtained from a parametric function $C(\mathbf{h})$, where $\mathbf{h}$ is the lag vector separating two observations. In general this parametric function may vary with both the length and direction of $\mathbf{h}$, but here we assumed that the function is isotropic and varies only according to the length of $\mathbf{h}$, which we denote by $h$. It is common in the geostatistical literature for the spatialcovariance of a random variable to be expressed in terms of the variogram

$$
\gamma(h)=0.5 E\left(\{(x)-Z(x+h)\}^{2}\right)
$$

The full details for the calculation of $\mathbf{V}$ are given in Webster and Oliver (2007). To model the spatial covariance, we used the Matérn function, which has a smoothness parameter $v$. When $v$ is small the spatial process is rough, whereas for large $v$ it is smooth. We calculated an effective range, which depends both on $a$ and $v$, by using the distance at which the Matérn semi-variance equalled 95\% of the partial sill variance. The parameters of the Matérn function were obtained by maximum likelihood estimation (Lark, 2000). The validity of the fitted geostatistical models was confirmed by leave-one-out cross-validation. For each sampling site location $i=1, \ldots, n$, the value of the property at site $\boldsymbol{x}_{i}$ is predicted by simple kriging upon $\mathbf{z}^{*}{ }_{(-i)}$, the vector of observations excluding $Z^{*}\left(\boldsymbol{x}_{i}\right)$. The statistic

$$
\theta_{i}=\frac{\left\{z^{*}\left(x_{i}\right)-\tilde{Z}_{(-i)}^{*}\right\}^{2}}{\sigma_{(-i)}^{2}}
$$

where $\tilde{Z}_{(-i)}^{*}$ and $\sigma_{(i)}^{2}$ denote the kriging prediction and kriging variance at $\boldsymbol{x}_{i}$ when $Z^{*}\left(\boldsymbol{x}_{i}\right)$ is omitted from the transformed observation vector. If the fitted model is a valid representation of the spatial variation of the soil property, then $\theta=\left(\theta_{1}, \ldots, \theta_{n}\right)$ has a $\chi^{2}$ distribution with mean $\theta=1.0$ and median $\theta=0.455$ (Lark, 2002). The mean and median values of $\theta$ were also calculated for 1000 simulated realizations of the fitted model to determine the 90\% confidence limits. Moreover, the evaluation of the model was also verified by performing a likelihood ratio test. This test was used to compare the fits of the spatial and non-spatial models. The spatial analysis GeoR package was used for the spatial analyses (Ribiero and Diggle, 2001).

\section{Results and Discussion}

The largest variations in gene copy numbers across the Burgundy region were observed for the ammonia-oxidizing crenarchaeota (AOA) and total crenarchaeota, with densities ranging between less than $10^{2}$ (detection limit) to $9.8 \times 10^{4}$ and from $4.7 \times 10^{1}$ to $5.9 \times 10^{4}$ gene copies per ng of DNA, respectively (Figure 1, Supplementary Figure S2). In comparison, the abundance of ammonia-oxidizing bacteria (AOB) varied over two orders of magnitude, whereas the abundances of nitrate reducers and denitrifiers mostly varied within one order of magnitude. In accordance with the study of Leininger et al. (2006), which showed a good correlation between a membrane lipid biomarker of archaea and the amo $A$ gene copy numbers, we found that the abundance of the AOA and the total crenarchaeota were highly correlated $\left(R^{2}=0.72, P<0.001\right.$; Supplementary Figure S3). In most soils of the Burgundy region, the AOA were largely predominant over the AOB with a ratio of archaeal to bacterial amo $A$ copy numbers ranging from 10 to 400 in 77 out of 107 sites, as observed in other studies (Leininger et al., 2006; Nicol et al., 2008; Jia and Conrad, 2009). However, 9 sites without common characteristics had a AOA:AOB ratio ranging between 0.2 and 1 .

The relative abundance of coexisting communities is of fundamental interest in ecology (Weiher and Keddy, 1999). Therefore, we also calculated the ratios of the different bacterial $\mathrm{N}$-cycling genes to bacterial 16S rRNA copy numbers and that of the AOA to total crenarchaeal $16 \mathrm{~S}$ rRNA copy numbers to examine how the proportions of the different $\mathrm{N}$-cycling communities within the prokaryotic community vary across landscapes (Supplementary

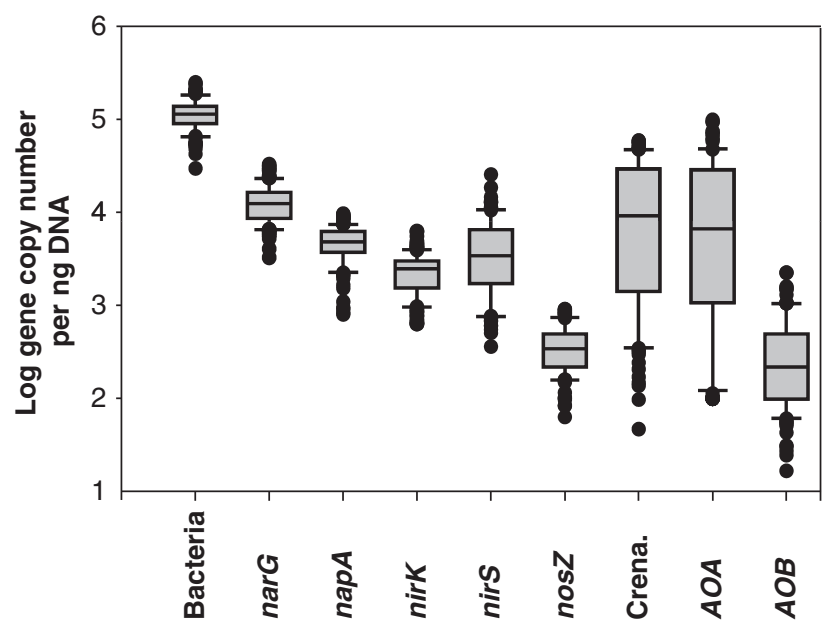

Figure 1 Variation in the abundance of different microbial communities across the Burgundy region. The upper and lower boundaries of each box indicate the 75th and 25th percentile, respectively, and the mid-line marks the median of the distribution of the corresponding qPCR values. Whiskers above and below the box indicate the 90th and 10th percentiles, respectively, while black dots indicate outliers. 
Table 1 Partitioning of the biological variation of different microbial communities as a function of contextual parameters

\begin{tabular}{|c|c|c|c|c|c|c|c|c|c|}
\hline & \multicolumn{3}{|c|}{ Overall model $^{\mathrm{a}}$} & \multicolumn{6}{|c|}{ Respective contribution of contextual variables (\% explained variance) ${ }^{\mathrm{b}}$} \\
\hline & $\mathrm{N}$ & $F$-ratio & $\begin{array}{c}\text { Total explained } \\
\text { variance }(\%)\end{array}$ & Space & $\begin{array}{l}\text { Land } \\
\text { use }\end{array}$ & Climate & Time & $\begin{array}{c}\text { Soil } \\
\text { physics }\end{array}$ & $\begin{array}{c}\text { Soil } \\
\text { chemistry }\end{array}$ \\
\hline Total bacteria & 16 & $14.81 * * *$ & 73.1 & $7.70^{* * *}$ & & $19.7 * * *$ & & $6.5 * * *$ & $20.8^{* * *}$ \\
\hline Total crenarchaea & 16 & $27.01 * * *$ & 85.1 & $1.3^{* *}$ & $1.6^{*}$ & $0.3 \mathrm{NS}$ & & $1.4^{*}$ & $25.2^{* * *}$ \\
\hline \multicolumn{10}{|l|}{ Nitrate reducers } \\
\hline narG & 25 & $17.33^{* * *}$ & 55.0 & $14.6^{* * *}$ & & $1.4^{*}$ & $0.6 \mathrm{NS}$ & $2.3 * *$ & $39.1 * * *$ \\
\hline $\operatorname{nap} A$ & 16 & $10.89 * * *$ & 66.7 & $6.0 * *$ & & & $6.6^{* *}$ & $3.9 * *$ & $49.5^{* * *}$ \\
\hline \multicolumn{10}{|l|}{ Denitrifiers } \\
\hline nirK & 12 & $18.64^{* * *}$ & 71.1 & & & & & $2.8 * *$ & $59.3 * * *$ \\
\hline $\operatorname{nirS}$ & 21 & $16.99 * * *$ & 83.0 & $2.2^{* *}$ & $0.5 \mathrm{NS}$ & $1.6^{* *}$ & $2.1^{* *}$ & $1.2^{*}$ & $35.5^{* * *}$ \\
\hline nos $Z$ & 10 & $17.08^{* * *}$ & 64.7 & $3.8^{* *}$ & & $5.2^{* *}$ & & $2.3^{*}$ & $41.3^{* * *}$ \\
\hline \multicolumn{10}{|l|}{ Nitrifiers } \\
\hline$A O B$ & 8 & $22.59 * * *$ & 70.8 & & $18.6 * * *$ & & & $1.3^{*}$ & $16.9 * * *$ \\
\hline$A O A$ & 15 & $25.65 * * *$ & 83.5 & & $1.1 \mathrm{NS}$ & & & $0.9^{*}$ & $26.9 * * *$ \\
\hline
\end{tabular}

${ }^{\mathrm{a}}$ For each quantitative response variable, redundancy analysis models were assessed for significance after selecting the most parsimonious explanatory variables by minimizing the Akaike Information Criterion. $N$, number of retained explanatory variables (details about the individual variables can be found in Table 2). Total explained variance consists of the sum of the respective contributions of each contextual category and of their overall covariation.

${ }^{\mathrm{b}}$ The biological variation in each model was partitioned into the respective effects of different categories of explanatory variables by using partial redundancy analyses and by adjusting $R^{2}$ values (that is, the percentage of explained variation) to obtain unbiased estimates (Peres-Neto et al., 2006).

Significance was determined by 1000 permutations with ${ }^{* *} P<0.001 ;{ }^{*} P<0.01 ;{ }^{*} P<0.05$; and NS (not significant), $P \geqslant 0.05$.

Figure S4). Interestingly, the AOA to crenarchaeota ratio varied from 0.08 to 2.7 , which suggests that (i) not all crenarchaea have the amo $A$ gene and are therefore capable of ammonia oxidation and (ii) the proportion of ammonia oxidizers within the crenarchaea is not constant in terrestrial environments and is influenced by environmental changes. However, this might also be partly explained by a variation in the number of amoA and 16S rRNA gene copies per cell and/or by the specificity of the primers used. Thus, ratios higher than 1 are likely due to the fact that the crenarchaea primers are not truly universal and are underestimating the total number of crenarchaea. We found that the nitrate reducers, denitrifiers and AOB represented around 5-20\%, $1-5 \%$ and $0.05-1 \%$ of the total bacterial community, respectively, as previously reported (Okano et al., 2004; Henry et al., 2006; Philippot et al., 2009b). It is noteworthy that the percentage of bacteria possessing the nos $Z$ gene, which encodes the $\mathrm{N}_{2} \mathrm{O}$ reductase, within the denitrifying community (that is, those possessing the nirK or nirS genes encoding a nitrite reductase) varied within one order of magnitude and was never higher than $56 \%$. This is consistent with the work of Jones et al. (2008), which showed that out of approximately $68 \mathrm{com}-$ plete prokaryotic genomes in the database with either nirS or nirK, only 43 had the nosZ gene. Our findings support the mounting evidence that a significant fraction of the denitrifying community might lack the genetic ability to perform the last step of the reduction pathway, that is, reduction of the potent greenhouse gas $\mathrm{N}_{2} \mathrm{O}$ into harmless $\mathrm{N}_{2}$ (Henry et al., 2006; Richardson et al., 2009; Philippot et al., 2009b).

Using a dataset describing 49 different soil and environmental variables at each sampling site (Supplementary Table S1), we found that between 43 and $85 \%$ of the biological variance in the distribution of the studied communities could be explained (Table 1 and Supplementary Table S2). The amounts of explained variation belonged to the upper range of what has been evidenced in other studies in microbial ecology (Yergeau et al., online first; Ramette and Tiedje, 2007b), or in classical community ecology (Cottenie, 2005) using comparable statistical approaches. To better understand the mechanisms driving the spatial distributions observed in this study, all variables were grouped into five categories (spatial effects, land use, climate, soil physics and soil chemistry), and partial regression models were calculated for each dataset (Table 1 and Supplementary Table S2). In almost all cases, soil chemistry was the strongest predictor and explained between 20 and $68 \%$ of the total variance (Table 1). When separating the effect of each variable, $\mathrm{pH}$ emerged as either an important or the strongest single soil chemistry predictor for most communities (Table 2). Thus, differences in soil $\mathrm{pH}$ alone could explain up to $17.8 \%$ of the variability in abundance of the total bacterial community, between 15.6 and $21.4 \%$ for the denitrifier community, $8.5 \%$ for the AOA and $2.9-7.1 \%$ for the nitratereducing community. The importance of soil $\mathrm{pH}$ has 
Table 2 Contribution of the first five most important explanatory variables to the variation in microbial community abundances

\% Variance explained by:

\begin{tabular}{|c|c|c|c|c|c|}
\hline $\begin{array}{l}\text { Total bacteria } \\
\text { Total crenarchaea }\end{array}$ & $\begin{array}{l}\mathrm{pH}(17.8) \\
\mathrm{pH}(9.6)\end{array}$ & $\begin{array}{c}\mathrm{Tp}_{\mathrm{M}}(13.1) \\
\mathrm{K}_{\mathrm{tot}}(5.6)\end{array}$ & $\begin{array}{l}\text { Sp. Dist.y }(7.1) \\
\operatorname{Mg}_{\text {tot }}(4.5)\end{array}$ & $\begin{array}{l}\text { Rain (6.0) } \\
\text { Res. water (3.8) }\end{array}$ & $\begin{array}{l}\mathrm{Cr}_{\text {ext }}(6.0) \\
\mathrm{Cd}_{\text {ext }}(3.3)\end{array}$ \\
\hline \multicolumn{6}{|l|}{ Nitrate reducers } \\
\hline NarG & Carbon (7.6) & $\mathrm{pH}(7.1)$ & Sp. Dist.v11 (5.6) & Sp. Dist.v7 (4.5) & $\mathrm{Mn}_{\text {exch }}$ (4.2) \\
\hline $\operatorname{nap} A$ & $\mathrm{Mn}_{\text {exch }}(7.4)$ & Time (6.6) & $\mathrm{Pb}(6.2)$ & Sp. Dist.x (6.0) & $\mathrm{Cu}_{\text {ext }}(5.2)$ \\
\hline \multicolumn{6}{|l|}{ Denitrifiers } \\
\hline nirK & pH (21.4) & $\mathrm{Cu}_{\text {tot }}(7.3)$ & Cr (6.0) & $\mathrm{Fe}_{\text {tot }}(5.4)$ & B (5.1) \\
\hline nirS & $\mathrm{pH}(15.6)$ & $\mathrm{Mn}_{\text {exch }}(6.4)$ & $\mathrm{Mn}_{\text {tot }}(4.8)$ & $\mathrm{Ca}_{\text {tot }}(4.5)$ & $\mathrm{Na}_{\text {tot }}(2.8)$ \\
\hline nos $Z$ & $\mathrm{pH}(15.9)$ & $\mathrm{Mn}_{\text {exch }}(8.5)$ & $\mathrm{Na}_{\text {exch }}(5.7)$ & $\mathrm{K}_{\text {tot }}(5.5)$ & $\mathrm{Tp}_{\mathrm{M}}(5.2)$ \\
\hline \multicolumn{6}{|l|}{ Nitrifiers } \\
\hline$A O B$ & Land use (18.6) & Carbon (8.4) & Ni (6.6) & $\mathrm{Na}_{\text {exch }}(5.3)$ & $\mathrm{K}_{\text {exch }}(3.3)$ \\
\hline$A O A$ & $\mathrm{pH}(8.5)$ & $\mathrm{K}_{\text {tot }}(5.5)$ & $\mathrm{Mg}_{\text {tot }}(3.6)$ & $\mathrm{Pb}_{\text {tot }}(3.2)$ & $\mathrm{P}_{\text {ass }}(2.7)$ \\
\hline \multicolumn{6}{|c|}{ Relative abundances } \\
\hline narG/16S & Carbon (23.0) & Sp. Dist.y (15.1) & $\mathrm{Na}_{\text {tot }}(8.9)$ & $\mathrm{Mn}_{\text {tot }}(6.1)$ & $\operatorname{Rain}_{\mathrm{yr}}(5.5)$ \\
\hline napA/16S & $\mathrm{Ca}_{\text {exch }}(32.0)$ & Res. water (5.4) & $\operatorname{ETP}_{\mathrm{M}}(4.3)$ & - & - \\
\hline nirK/16S & $\mathrm{Ca}_{\text {exch }}(16.8)$ & Res. water (10.2) & $\mathrm{Tp}_{\mathrm{M}}(9.8)$ & - & - \\
\hline nirS/16S & $\mathrm{Na}_{\text {tot }}(9.8)$ & $\mathrm{P}_{\mathrm{ass}}(8.0)$ & $\operatorname{Rain}_{\mathrm{yr}}(6.8)$ & $\mathrm{Mn}_{\text {tot }}(5.4)$ & $\mathrm{K}_{\text {tot }}(5.3)$ \\
\hline nosZ/16S & Sp. Dist.y (9.6) & - & - & - & - \\
\hline AOB/16S & Land (18.0) & $\mathrm{Ni}_{\text {ext }}(9.3)$ & $\mathrm{Ca}_{\text {tot }}(6.3)$ & Nitrogen (5.7) & $\mathrm{Na}_{\text {exch }}(5.7)$ \\
\hline AOA/16S & pH (23.9) & Res. water (12.6) & Sand (8.3) & $\mathrm{Fe}_{\text {tot }}(7.2)$ & $\mathrm{Mn}_{\text {exch }}$ (5.3) \\
\hline AOA/AOB & $\mathrm{pH}(12.0)$ & $K_{\text {tot }}(9.9)$ & Nitrogen (7.8) & $K_{\text {exch }}(6.6)$ & $\mathrm{Mn}_{\text {tot }}(4.1)$ \\
\hline
\end{tabular}

The respective contributions were calculated by taking into account all other significant variables in the model using partial redundancy analyses and adjusting the $R^{2}$ values (see Table 1). Only significant fractions based on 1000 data permutations and subsequent multiple-comparison Bonferroni corrections are reported. Subscripts are: M (monthly), Sp. Dist. (spatial distance with the corresponding spatial variables indicated as subscripts), Res. water (residual water), ass (assimilable), tot (total), ext (extractable), exch (exchangeable) and yr (year).

been widely documented for both the total bacterial community and the microbial communities involved in N-cycling (Fierer and Jackson, 2006; Philippot et al., 2007; Hartman et al., 2008; Nicol et al., 2008; Hallin et al., 2009). Despite the fact that soil $\mathrm{pH}$ is now recognized as a driver of changes in AOA and AOB communities (Prosser and Nicol, 2008; Erguder et al., 2009), the way in which $\mathrm{pH}$ affects AOA communities is still debated and controversial. Thus, decreasing of AOA abundance has been reported both with decreasing soil $\mathrm{pH}$ (He et al., 2007; Hallin et al., 2009; Jia and Conrad, 2009) and with increasing soil pH (Nicol et al., 2008). In our study, which included 107 soils with $\mathrm{pH}$ ranging from 4.2 to 8.3 , we found that the $\mathrm{AOA}$ were below the detection limit only in acidic soils and that soil $\mathrm{pH}$ was positively correlated with AOA abundance $\left(R^{2}=0.424, P<0.001\right)$. Soil $\mathrm{pH}$ was also the best predictor of the AOB/AOA ratio with $12 \%$ of the variance explained $(P<0.001)$. Although soil $\mathrm{pH}$ has been shown to influence the abundance of AOB (He et al., 2007; Hallin et al., 2009), it was not a significant factor across the large range of soils examined here. This suggests that $\mathrm{pH}$ may be important only in regulating AOB on smaller scales or across specific fertilization regimes (Fierer et al., 2009). Altogether, our results indicate that niche partitioning between $\mathrm{AOB}$ and $\mathrm{AOA}$ is largely attributable to soil $\mathrm{pH}$, with AOA being more affected by acidic $\mathrm{pH}$ than AOB. Interestingly, we also found that the $24 \%$ spatial variability of the AOA/crenarchaea ratio could also be explained by changes in $\mathrm{pH}$, which suggests a stronger effect of soil $\mathrm{pH}$ on the crenarchaeal ammonia oxidizers than on the rest of the crenarchaeal community. Evidence of $\mathrm{AOA}$ and $\mathrm{AOB}$ specific niches in terrestrial environments is strengthened by the findings that none of the 42 measured soil properties at the sampling sites could explain the variation in both the abundances of AOA and AOB (Table 2). Among the soil chemical properties other than $\mathrm{pH}$ that explained the variance in distribution of the different N-cycling communities, exchangeable manganese availability was a significant predictor of the abundance of the nitrate reducers $(4.2-7.4 \%)$ and of the denitrifiers (5.0-8.5\%) (Table 2). In contrast to soil chemistry, the relative contribution of soil physics was never higher than $6.5 \%$ of the variability, although significant for several functional communities (Table 1). Altogether, these findings demonstrate that a very significant proportion of the variation in the distribution of microbial guilds can be predicted across terrestrial ecosystems at the landscape scale.

Three dominant types of ecosystems were distinguished across the 107 Burgundy sites, with forests (with 21 out of 26 being deciduous forests), grasslands and agricultural soils dominating. We found that changes in land use did not strongly influence the abundance of any of the studied communities 
other than the AOB, for which $18.6 \%$ of the variation could be explained by the pure effects of that factor alone (Table 1). Changes in land use also affected the proportion of AOB within the total bacterial community, further suggesting an inherent sensitivity of this community to land management (Table 2). This coupling between land use managements and abundance of AOB indicates that AOB abundance could be used as a pertinent biological indicator for monitoring soils. Likewise, AOB diversity is affected by land use (Carney et al., 2004) and was recently selected as a top candidate biological indicator of soil quality for national-scale soil monitoring (Ritz et al., 2004).

To examine the relative contribution of climatic variables to the landscape distributions of the functional microbial communities, we used regional patterns of precipitation, net evapotranspiration and temperature data (Supplementary Table S1). Despite important variations, local climate mostly had a significant influence on the distribution pattern of the total bacterial community, with temperature, precipitation and evapotranspiration significantly explaining 13.1, 6.0 and $5.6 \%$ of the total variance, respectively (Table 2). We also found that local climate explained around $10-13 \%$ of the variability in the relative abundance of nirS and nirK denitrifiers within the total bacterial community (Supplementary Table S2). When considered separately from the other factors, the sampling period (time) had a weak influence and affected significantly only the napA and nirS communities (\% variance explained of 6.6 and 2.1, respectively), thus indicating that the large time period needed to sample all 107 sites did not strongly affect our results by masking the effects of other environmental variables. Likewise, a recent study reported that temporal variation also had little impact on the distribution of the microbial community composition, despite being sampled in different seasons and different years (Drenovsky et al., 2010). Altogether, the results show that neither local climate nor the sampling time was a major factor influencing the distribution patterns of the studied N-cycling communities over the $31500 \mathrm{~km}^{2}$ Burgundy region.

Geographical distance, when separated from the other environmental variables, was a weak but significant predictor of the total bacterial and crenarchaeal communities and of the nitratereducing and -denitrifying communities (Table 1). However, the explanatory power of the spatial distance dramatically increased when spatial autocorrelation was explicitly modelled without dissecting the environmental variables and incorporating covariation. Thus, by investigating the spatial correlation of microbial abundance using a geostatistical approach, we found strong spatial patterns in the distribution of some communities, with autocorrelation ranging between 22 and $739 \mathrm{~km}$ (practical ranges in supplementary Table S3). Three major types of spatial distributions were found.
The predicted map of the distribution of total bacteria was quite smooth with a high density in the north and a low density in the south, while the crenarchaea exhibited a more patchy distribution (Figure 2). Finally, the maps of nirK and nirS are

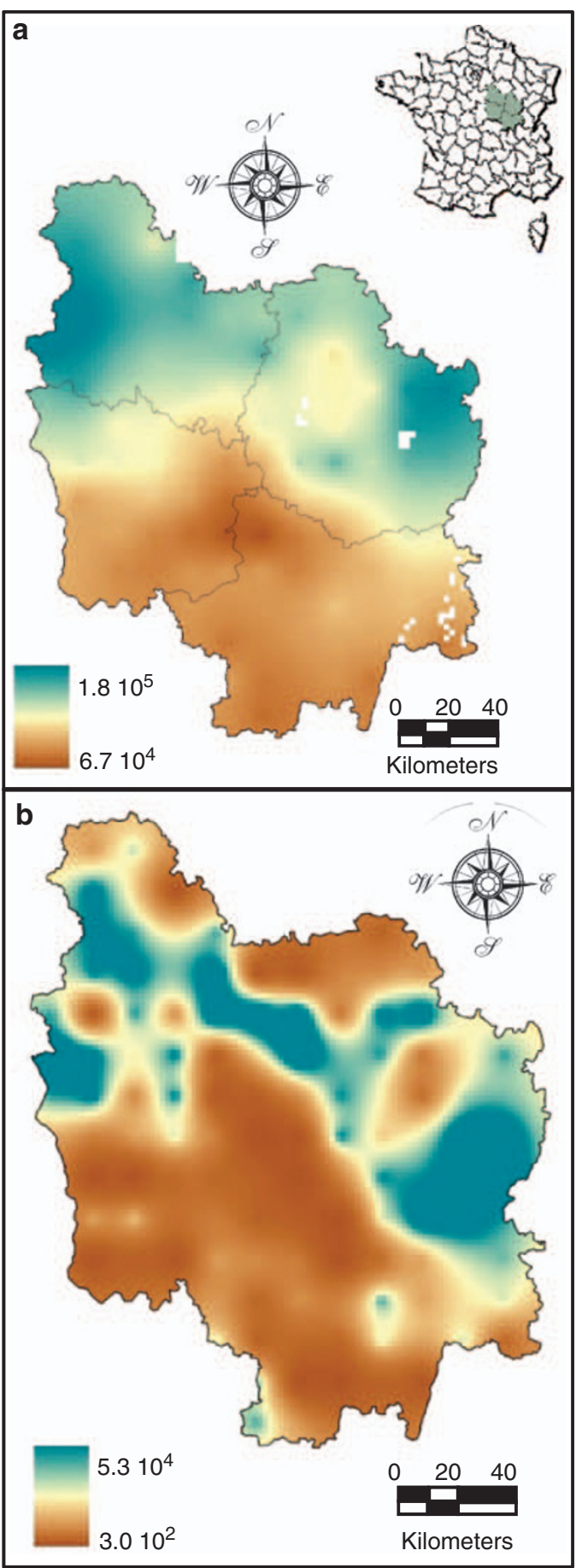

Figure 2 Maps of the abundances of total bacteria and crenarchaea in Burgundy. (a) Bacterial 16S rRNA, (b) crenarchaeal 16S rRNA. The color scale to the left of each map indicates the extrapolated abundance values (gene copy number per ng of DNA). 


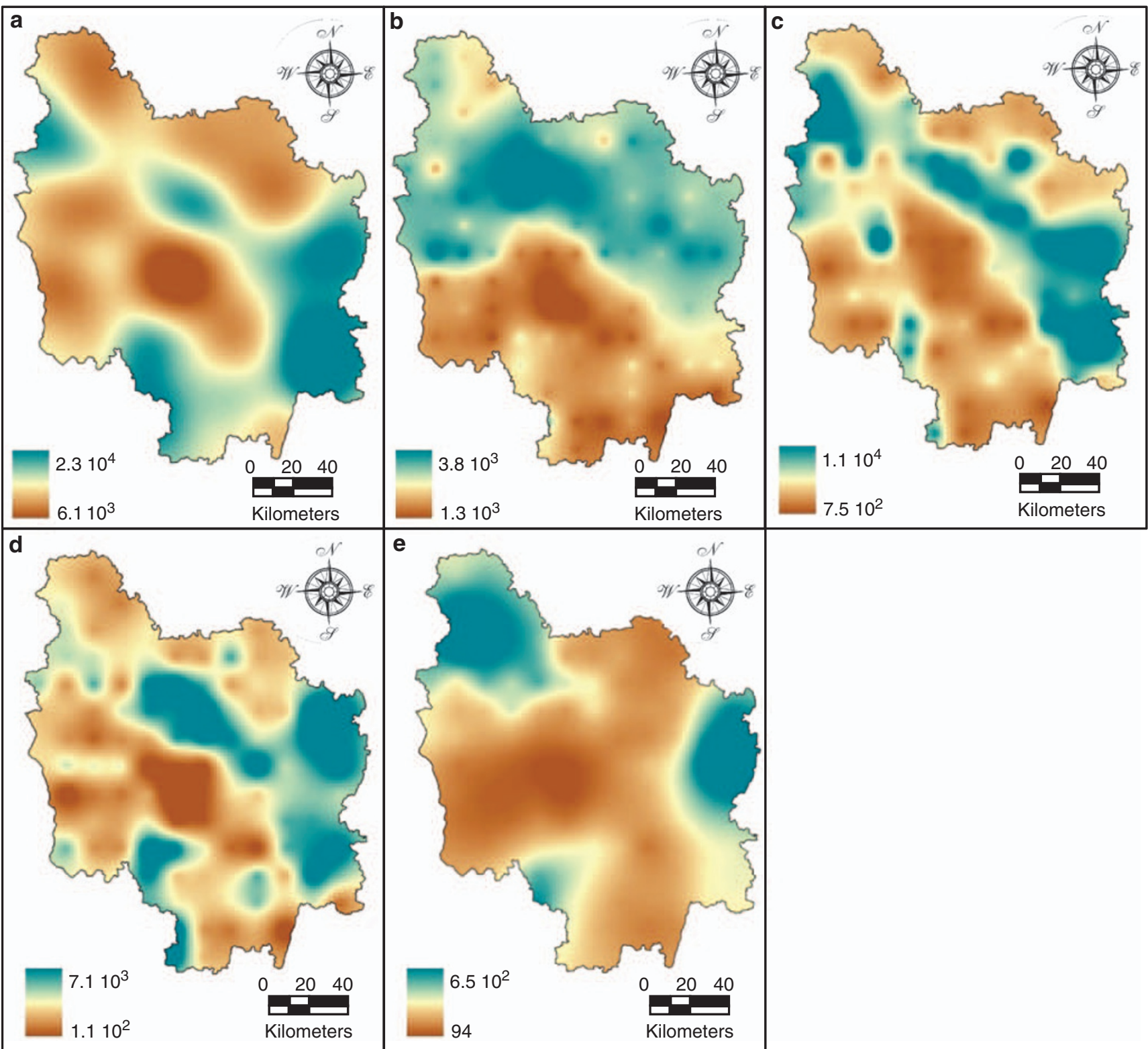

Figure 3 Maps of the abundances of N-cycling genes in Burgundy. (a) narG, (b) nirK, (c) nirS, (d) nosZ, (e) AOB. The color scale to the left of each map indicates the extrapolated abundance values (gene copy number per ng of DNA).

somewhat 'spotty'. These three types of maps are directly related to the roughness of the spatial distributions, which were modelled thanks to the flexibility of Matérn variogram. Interestingly, the significant latitude effect observed both for the distribution of the total bacterial community and also for the relative abundance of the narG and nos $Z$ genes (Table 2, Supplementary Figure S5) was related to the distribution of soil parental material with limestone plateau in northern Burgundy and crystalline rocks in southern Burgundy. Few differences were observed between the distributions of the nirS and nos $Z$ denitrifiers, while the distribution of the nirK denitrifiers was more related to that of the total bacteria (Figure 3). In contrast, the predicted map of AOB distribution differed considerably from that of all the other studied communities (Figure 3). Those maps supported the results of the canonical variation partitioning analyses, indicating that the AOB was the only community for which soil chemistry was not the main determinant of the spatial distribution (Table 1). Although we know of no other directly comparable studies, a few articles have reported spatial dependence of the distribution of microbial abundance at much lower scales ranging from centimetres to tens of meters (Franklin et al., 2002; Ritz et al., 2004; Philippot et al., 2009b; Enwall et al., 2010). At larger scales, studies using a spatially explicit approach have focused on microbial diversity rather than on 
microbial abundance. Thus, spatial dependence of microbial diversity at a kilometer scale was observed by Dequiedt et al. (2009) and Cho and Tiedje (2000), while Fierer and Jackson (2006) found that microbial diversity was not related to geographic distance across North and South America. Although spatial variability in the distributions of soil microorganisms is generally regarded as random noise, our results revealed that this variability can be explained even at the landscape scale.

In conclusion, the present study provides an overview of the factors driving the spatial distribution of microbial communities involved in N-cycling and of the total bacterial and crenarchaeal communities across a $31500 \mathrm{~km}^{2}$ terrestrial landscape. Our spatially explicit approach showed that no single biogeographical distribution was shared by all the studied microbial communities. However, some common features emerged and soil chemistry-with $\mathrm{pH}$ as an overarching controlling factor-was the most important predictor of the distribution of the microbial communities in many cases. Thus, although many environmental variables were significant predictors, only a few accounted for a large amount of the total variance in the distribution of the studied microbial guilds and we could explain between 43 and $85 \%$ of this spatial variation in community abundances. Furthermore, our findings illustrate the potential of geostatistic methods, which were successfully used to produce the first maps of the distribution of microbial guilds at a scale of relevance to policy makers and stakeholders for ecosystem management.

\section{Acknowledgements}

Sampling and soil analyses were supported by a French Scientific Group of Interest on Soils: the 'GIS Sol', involving the French Ministry for Ecology and Sustainable Development, the French Ministry of Agriculture, the French Agency for Energy and Environment (ADEME), the National Institute for Agronomic Research (INRA), the Institute for Research and Development (IRD) and the National Forest Inventory (IFN). We are grateful to all the soil surveyors and technical assistants involved in sampling the sites: Chambers of Agriculture of Côte-d'Or, Nièvre, Saône-et-Loire, Yonne and National Institute for Agronomy, Food and Environment (AgroSup Dijon). This project was funded by the Burgundy region and the French National Research Agency (ANR).

\section{References}

Borcard D, Legendre P. (2002). All-scale spatial analysis of ecological data by means of principal coordinates of neighbour matrices. Ecol Model 153: 51-68.

Borcard D, Legendre P, Avois-Jacquet C. (2004). Dissecting the spatial structure of ecological data at multiple scales. Ecology 85: 1826-1832.
Borcard D, Legendre P, Drapeau P. (1992). Partialling out the spatial component of ecological variation. Ecology 73: $1045-1055$.

Box GEP, Cox DR. (1964). An analysis of transformation. J Royal Stat Soc 26: 211-243.

Bru D, Sarr A, Philippot L. (2007). Relative abundances of proteobacterial membrane-bound and periplasmic nitrate reductases in selected environments. Appl Environ Microbiol 73: 5971-5974.

Carney KC, Matson PA, Bohannan BJM. (2004). Diversity and composition of tropical soil nitrifiers across a plant diversity gradient and among land-use types. Ecol Lett 7: 684-694.

Cho J-C, Tiedje JM. (2000). Biogeography and degree of endicity of fluorescent Pseudomonas strains in soil. Appl Environ Microbiol 66: 5448-5456.

Cook RD, Weisberg S. (1999). Wiley series in probability and statistics. In: Statistics, W.S.i.P.a. (ed) Applied Regression, Including Computing and Graphics. Wiley-Interscience.

Cottenie K. (2005). Integrating environmental and spatial processes in ecology community dynamics. Ecol Lett 8: $1175-1182$.

Dequiedt S, Thioulouse J, Jolivet C, Saby N, Lelievre M, Maron P-A. et al. (2009). Biogeographical patterns of soil bacterial communities. Environ Microbiol Rep 1: 251-255.

Drenovsky RE, Steenwerth KL, Jackson LE, Scow KM. (2010). Land use and climatic factors structure regional patterns in soil microbial communities. Global Ecol Biogeogr 19: 27-39.

Enwall K, Throbäck N, Stenberg M, Söderström M, Hallin S. (2010). Soil resources influence spatial patterns of denitrifying communities at scale compatible with land use management. Appl Environ Microbiol 76: 2243-2250.

Erguder TH, Boon N, Wittebolle L, Marzorati M, Verstraete W. (2009). Environmental factors shaping the ecological niches of ammonia-oxidizing archaea. FEMS Microbiol Rev 33: 855-869.

Fierer N, Carney KM, Horner-Devine MC, Megonigal JP. (2009). The biogeography of ammonia-oxidizing bacterial communities in soil. Ecol 58: 435-445.

Fierer N, Jackson R. (2006). The diversity and biogeography of soil bacterial communities. Proc Natl Acad Sci USA 10: 626-631.

Forster P, Ramaswamy V, Artaxo P, Berntsen T, Betts R, Fahey DW et al. (2007) In: Solomon S, et al. (eds). Climate Change 2007: Changes in atmospheric constituents and in radiative forcing. The Physical Science Basis. Contribution of Working Group I to the Fourth Assessment Report of the Intergovernmental Panel on Climate Change. Cambridge University Press: Cambridge, UK,and New York, NY, USA.

Franklin R, Mills A. (2003). Multi-scale variation in spatial heterogeneity for microbial community structure in an eastern Virginia agricultural field. FEMS Microbiol Ecol 44: 335-346.

Franklin RM, Blum LK, McComb AC, Mills AL. (2002). A geostatistical analysis of small-scale spatial variability in bacterial abundance and community structure in salt marsh creek bank sediments. FEMS Microbiol Ecol 42: 71-80.

Green JL, Bohannan BJM, Whitaker RJ. (2008). Microbial biogeography: from taxonomy to traits. Science 320: 1039-1043.

Hallin S, Jones CM, Schloter M, Philippot L. (2009). Relationship between N-cycling communities and 
ecosystem functioning in a 50-year-old fertilization experiment. ISME J 3: 597-605.

Hartman WH, Richardson CJ, Vilgalys R, Bruland GL. (2008). Environmental and anthropogenic controls over bacterial communities in wetland soils. Proc Natl Acad Sci USA 105: 17842-17847.

He JZ, Shen JP, Zhang LM, Zhu YG, Zheng YM, Xu MG et al. (2007). Quantitative analyses of the abundance and composition of ammonia-oxidizing bacteria and ammonia-oxidizing archaea of a Chinese upland red soil under long-term fertilization practices. Environ Microbiol 9: 2364-2374.

Henry S, Baudoin E, Lopez-Gutierrez JC, Martin-Laurent F, Brauman A, Philippot L. (2004). Quantification of denitrifying bacteria in soils by nirK gene targeted real-time PCR. J Microbiol Methods 59: 327-335. Corrigendum (2005) 61:289-290.

Henry S, Bru D, Stress B, Hallet S, Philippot L. (2006). Quantitative detection of the nos $Z$ gene, encoding nitrous oxide reductase, and comparison of the abundances of $16 \mathrm{~S}$ rRNA, narG, nirk, and nos $Z$ genes in soils. Appl Environ Microbiol 72: 5181-5189.

Heymann Y, Steenmas C, Croissille G, Bossard M. (1994). Corine Land Cover-Technical Guide. Office for Official Publications of the European Communities: Luxemberg, p 144, ISBN 92-826-2578-8.

Hughes-Martiny JB, Bohannan BJM, Brown JH, Colwell RK, Fuhrman JA, Green JL et al. (2006). Microbial biogeography: putting microorganisms on the map. Rev Microbiol 4: 102-112.

Hutchinson GE. (1953). The concept of pattern in ecology. Proc Acad Nat Sci Phila 105: 1-12.

Jia Z, Conrad R. (2009). Bacteria rather than Archaea dominate microbial ammonia oxidation in an agricultural soil. Environ Microbiol 11: 1658-1671.

Jones CM, Stres B, Rosenquist M, Hallin S. (2008). Phylogenetic analysis of nitrite, nitric oxide, and nitrous oxide respiratory enzymes reveal a complex evolutionary history for denitrification. Mol Biol Evol 5: 1955-1966.

Klappenbach JA, Saxman PR, Cole JR, Scmidt TM. (2001). rrndb: the ribosomal RNA operon copy number database. Acid Res 29: 181-184.

Kowalchuk GA, Stephen JR. (2001). Ammonia-oxidizing bacteria: a model for molecular microbial ecology. Annu Rev Microbiol 55: 485-529.

Lark RM. (2000). A comparison of some robust estimators of the variogram for use in soil survey. Eur J Soil Sci 51: 137-157.

Lacarce E, Le Bas C, Cousin JL, Pesty B, Toutain B, Houston Durrant T et al. (2009). Data management for monitoring forest soils in Europe for the Biosoil project. Soil Use Manag 25: 57-65.

Lark RM. (2002). Modelling complex soil properties as contaminated regionalized variables. Geoderma 106: 173-190.

Leininger S, Urich T, Schloter M, Schwark L, Qi J, Nicol GW et al. (2006). Archaea predominate among ammonia-oxidizing prokaryotes in soils. Nature 442: 806-809.

Levin SA. (1992). The problem of pattern and scale in ecology. Ecology 73: 1943-1967.

Martin-Laurent F, Philippot L, Hallet S, Chaussod R, Germon JC, Soulas G et al. (2001). DNA extraction from soils: old bias for new microbial diversity analysis methods. Appl Environ Microbiol 67: 2354-2359.
Morvan X, Saby NPA, Arrouays D, Le Bas C, Jones RJA, Verheijen FGA et al. (2008). Soil monitoring in Europe: a review of existing systems and requirements for harmonisation. Sci Tot Environ 391: 1-12.

Nicol G, Leininger S, Schleper C, Prosser JI. (2008). The influence of soil $\mathrm{pH}$ on the diversity, abundance and transcriptional activity of ammonia oxidizing archaea and bacteria. Environ Microbiol 10: 2966-2978.

Nunan N, Wu K, Young IM, Crawford JW, Ritz K. (2002). In situ spatial patterns of soil bacterial populations, mapped at multiple scales, in an arable soil. Microbiol Ecol 44: 296-305.

Ochsenrelter T, Selezi D, Qualser A, Bonch-Osmolovskaya L, Schleper C. (2003). Diversity and abundance of Crenarchaeota in terrestrial habitats studied by $16 \mathrm{~S}$ RNA surveys and real time PCR. Environ Microbiol 5: 787-797.

Okano Y, Hristova KR, Leutenegger CM, Jackson LE, Denison RF, Gebreyeys B et al. (2004). Application of real-time PCR to study effects of ammonium on population size of ammonia-oxidizing bacteria in soil. Appl Environ Microbiol 70: 1008-1016.

Peres-Neto P, Legendre P, Dray S, Borcard D. (2006). Variation partitioning of species data matrices: estimation and comparison of fractions. Ecol 87: 2614-2625

Philippot L, Bru D, Saby NPA, Cuhel J, Arrouays D, Simek M et al. (2009a). Spatial patterns of bacterial taxa in nature reflect ecological traits of deep brances of the 16S rRNA bacterial tree. Environ Microbiol 11: 1518-1526.

Philippot L, Cuhel J, Saby NPA, Chèneby D, Chronakova A, Bru D et al. (2009b). Mapping field-scale spatial distribution patterns of size and activity of the denitrifier community. Environ Microbiol 11: 15181526.

Philippot L, Hallin S. (2005). Finding the missing link between diversity and activity using denitrifying bacteria as a model functional community. Curr Opin Microbiol 8: 234-239.

Philippot L, Hallin S, Schloter M. (2007). Ecology of denitrifying prokaryotes in agricultural soil. $A d v$ Agronomy 96: 135-190.

Prosser JI, Nicol GW. (2008). Relative contributions of archaea and bacteria to aerobic ammonia oxidation in the environment. Environ Microbiol 10: 2931-2941.

Quintana-Segui P, Moigne PL, Durand Y, Martin E, Habets F, Baillon M et al. (2008). Analysis of near-surface atmospheric variables: validation of the SAFRAN analysis over France. J Appl Meteo Climat 47: 92-107.

Ramette A, Tiedje JM. (2007a). Biogeography: an emerging cornerstone for understanding prokaryotic diversity, ecology and evolution. Microbiol Ecol 53: 197-207.

Ramette A, Tiedje JM. (2007b). Multiscale responses of microbial life to spatial distance and environmental heterogeneity in a patchy ecosystem. Proc Natl Acad Sci USA 104: 2761-2766.

Ravishankara AR, Daniel JS, Portmann RW. (2009). Nitrous oxide $\left(\mathrm{N}_{2} \mathrm{O}\right)$ : the dominant ozone-depleting substance emitted in the 21st Century. Science 326: 123-125.

Ribiero PJ, Diggle PJ. (2001). geoR: a package for geostatistical analysis. $R$ news 1: 8-15.

Richardson D, Felgate H, Watmough N, Thomson A, Baggs E. (2009). Mitigating release of the potent greenhouse gas $\mathrm{N} 2 \mathrm{O}$ from the nitrogen cycle-could enzymic regulation hold the key? Trends Biotech 27: 388-397. 
Ritz K, McNicol JW, Nunan N, Grayston S, Millard P, Atkinson D et al. (2004). Spatial structure in soil chemical and microbiological properties in an upland grassland. FEMS Microbiol Ecol 49: 191-205.

Tourna M, Freitag TE, Nicol GW, Prosser JI. (2008). Growth, activity and temperature responses of ammonia-oxidizing archaea and bacteria in soil microcosms. Environ Microbiol 10: 1357-1364.

Webster R, Oliver M (eds) Geostatistic for Environmental Scientists. John Wiley \& Sons Ltd.: Chichester, UK, 2007.
Weiher E, Keddy PA. (1995). Assembly rules, null models, and traits dispersion: new questions from old patterns. Oikos 74: 159-164.

Weiher E, Keddy PA. (1999). Relative abundance and evenness patterns along diversity and biomass gradients. Oikos 87: 355-361.

Yergeau E, Bezemer TM, Hedlund K, Mortimer SR, Kowalchuk GA, van der Putten WH. (2009). Influence of space, soil, nematode and plants on microbial community composition of chalk grassland soils. Environ Microbiol (e-pub ahead of print 16 September 2009) doi: 10.1111/j.1462-2920.2009.02053.x.

Supplementary Information accompanies the paper on The ISME Journal website (http://www.nature.com/ismej) 